Int. J. Electrochem. Sci., 16 (2021) Article ID: 21062

International Journal of

ELECTROCHEMICAL

SCIENCE

www.electrochemsci.org

\title{
Corrosion Behavior of 3A21 Aluminum Alloy in Water- Ethylene Glycol Coolant under Simulated Engine Working Conditions
}

Hanyang Zuo ${ }^{1,3}$, Jinlong Fan ${ }^{1,3}$, Feng Liu ${ }^{1,3}$, Min Gong ${ }^{1,3, *}$, Xingwen Zheng ${ }^{2,3}$, Junchen Meng ${ }^{1,3}$, Guangming Yang ${ }^{1,3}$, Xiaohua Liu ${ }^{1,3}$

${ }^{1}$ School of Material and Science Engineering, Sichuan University of Science \& Engineering, Zigong 643000, China

${ }^{2}$ School of Chemical and Environmental Engineering, Sichuan University of Science \& Engineering, Zigong 643000, China

${ }^{3}$ Key Laboratory of Material Corrosion and Protection of Sichuan Province, Zigong 643000, China

*E-mail: gmsuse@126.com

doi: $10.20964 / 2021.06 .05$

Received: 23 December 2020 / Accepted: 26 March 2021 / Published: 30 April 2021

In this work, the corrosion behavior of 3A21 aluminum alloy in ethylene glycol coolant was studied under simulated working conditions of automotive engine. The conditions changed alternately between $25^{\circ} \mathrm{C}$ and $88^{\circ} \mathrm{C}$ were used to simulate automobile engine usage scenarios. Various methods were used to evaluate polarization resistance, corrosion morphology, element characteristics of corrosion products and corrosion rate. The electrochemical impedance spectroscopy (EIS) demonstrated that polarization resistance first increased and then decreased with the increasing immersion duration at $25^{\circ} \mathrm{C}$ and $88^{\circ} \mathrm{C}$ due to the formation of aluminum alloy oxide film and Al-alcohol film. X-ray photoelectron spectroscopy (XPS) confirmed the existence of Al-alcohol film. Energy dispersive spectrometer (EDS) shown that the content ratio between oxygen and aluminum $(\mathrm{O} / \mathrm{Al})$ in corrosion products of aluminum alloy surface decreased with increasing concentration of ethylene glycol, while the ratio of $\mathrm{C} / \mathrm{O}$ increased with the increasing concentration of ethylene glycol. The scanning electron microscope (SEM) results showed that there was pitting corrosion on the surface of 3A21 aluminum alloy. The results of mass loss corrosion experiments indicated that the corrosion rate of 3A21 aluminum alloy in ethylene glycol increased with the increasing of immersion duration and decreased with the increasing concentration of ethylene glycol. Corrosion rate decreased from $0.00512 \mathrm{~g} \cdot \mathrm{h}^{-1} \cdot \mathrm{m}^{-2}$ (in $0 \%$ ethylene glycol coolant) to $0.00226 \mathrm{~g} \cdot \mathrm{h}^{-1} \cdot \mathrm{m}^{-2}$ (in $65 \%$ ethylene glycol coolant) at $25^{\circ} \mathrm{C}-88^{\circ} \mathrm{C}$ alternately for 14 days. The mass loss corrosion rate decreased from $0.00908 \mathrm{~g} \cdot \mathrm{h}^{-1} \cdot \mathrm{m}^{-2}$ (in $0 \%$ ethylene glycol coolant) to $0.00396 \mathrm{~g} \cdot \mathrm{h}^{-1} \cdot \mathrm{m}^{-2}$ (in $65 \%$ ethylene glycol coolant) at $25^{\circ} \mathrm{C}-88^{\circ} \mathrm{C}$ alternately for 90 days.

Keyword: 3A21 aluminum alloy; Ethylene glycol coolant; Simulating condition; Automotive engine 


\section{FULL TEXT}

(C) 2021 The Authors. Published by ESG (www.electrochemsci.org). This article is an open access article distributed under the terms and conditions of the Creative Commons Attribution license (http://creativecommons.org/licenses/by/4.0/). 